\title{
SEABED ACOUSTIC CLASSIFICATION IN THE PELOTAS BASIN, BRAZIL
}

\author{
Paloma Lumi Costa*, Lauro A. Saint Pastous Madureira and Marcelo Peres de Pinho \\ Universidade Federal do Rio Grande \\ Instituto de Oceanografia - Laboratório de Tecnologia Pesqueira e Hidroacústica \\ (Campus Carreiros, Av. Itália, km 8, Caixa Postal 474, 96203-000 Rio Grande, RS, Brasil) \\ *Corresponding author: paloma.lumi@gmail.com
}

\begin{abstract}
A B S T R A C T
The present study sought to develop a seabed map of the region of the Pelotas Basin using acoustic methods. A total number of 1,507,823 seabed reflectivity data, collected during six oceanographic surveys, were processed to generate a seabed map. Data processing consisted of the classification of the acoustic parameter BSBS (Bottom Surface Backscattering Strength) obtained with the Scientific Echosounder EK 500 operating at a frequency of $38 \mathrm{kHz}$. BSBS is expressed in decibels $(\mathrm{dB})$, and corresponds to a logarithm of the ratio between incident acoustic energy and the energy reflected by the seabed. Four BSBS value classes, associated with different sediment types, were established. High BSBS values are associated with coarse sediments, whereas low values indicate fine sediments. A seabed reflectivity map was generated using the Natural Neighbor method to interpolate the BSBS values organized according to the pre-established classes. Four features with high BSBS values were identified at 100-200 m depth. The largest one was found in the region of Santa Marta Cape and attributed mainly to consolidated seabed and/or the presence of biodetritic material, according to comparison with maps available in the literature. Above $500 \mathrm{~m}$ depth, there was a predominance of acoustically low reflectivity sea floor, which was attributed to the presence of muddy sediment. Considering the lack of information on the seabed at great depths, the acoustic method was shown to be an alternative tool to obtain data on seabed characteristics in these regions.
\end{abstract}

\section{RESUMO}

O presente estudo teve como objetivo principal a realização de um mapeamento de fundo, através de metodologia acústica, para a região da Bacia de Pelotas. Um total de 1.507.823 dados de refletividade de fundo provenientes de seis Cruzeiros Oceanográficos foi processado para elaboração de um mapa de refletividade de fundo. Esse processamento consistiu numa classificação dos valores do parâmetro acústico BSBS adquirido pela sonda EK 500 a uma frequência de $38 \mathrm{kHz}$. Este parâmetro é disponibilizado em decibel (dB) e corresponde a uma relação logarítmica entre a energia incidente e a refletida pelo fundo marinho. Foram estabelecidas quatro classes de valores de BSBS as quais são associadas a tipos de sedimentos. Altos valores de BSBS são associados a sedimentos grosseiros enquanto baixos valores de BSBS são associados a sedimentos finos. Um mapa de refletividade de fundo foi gerado utilizando o método de interpolação Natural Neighbour dos valores de BSBS dispostos nas classes pré-estabelecidas. Quatro feições com altos valores de BSBS foram identificadas entre as profundidades de 100 e $200 \mathrm{~m}$, a maior delas na altura do Cabo de Santa Marta e atribuídas principalmente a fundos consolidados e/ou com presença de material biodetrítico quando comparado aos mapas disponíveis na literatura. Acima dos $500 \mathrm{~m}$ predominaram fundos com baixa refletividade acústica, atribuídos a presença de sedimento lamoso. Tendo em vista a escassez de informações sobre o leito marinho em grandes profundidades, o método acústico mostrou-se uma ferramenta alternativa para obter informações sobre característica de fundo nestas regiões.

Descriptors: Acoustic seabed classification, Pelotas Basin, Marine bottom sediments.

Descritores: Classificação acústica do fundo marinho, Bacia de Pelotas, Sedimentos do fundo marinho.

\section{INTRODUCTION}

The preservation of marine environments requires a strong scientific basis with detailed information on the complexity of the regions concerned. In ecological terms, the seabed is basic for interactions among ecosystems and is responsible for various processes that frequently influence the spatial distribution of species. The natural environment is hierarchically structured, and processes occur on space-time scales. The management of marine ecosystems therefore requires the definition and mapping of natural regions based on several biotic and abiotic aspects (ANDERSON et al., 2008), including space components and the variation of 
seafloor properties to determine the criteria for the establishment of protected areas or those inadequate for fishery activities.

Fishery management strategies and monitoring may be questionable if there is insufficient knowledge on the space scales where related processes operate. Thus it is that accurate mapping of the seabed may become an important decision-making tool. Detailed habitat maps are extremely useful to indicate where fishing resources can be caught and to make selection of the most appropriate fishing gear possible. These maps can also be used to identify sensitive areas which may need protection (HOGARTH et al., 2005).

Recent developments in acoustic technology have made it possible to describe and map marine environments. This is now done with high-resolution bathymetry data and seabed classification which identifies different habitats across a continuum of spatial scales (ANDERSON et al., 2002). Seabed classification employing acoustics is a recent science, largely driven by the development of commercial systems for the classification of superficial sediments and habitats of demersal species (ANDERSON et al., 2008).

Various methods based on different acoustic measurements have been developed for the purpose of describing seabed properties (ORLOWSKI, 1989; COLLINS et al., 1996; ANDERSON et al., 2002; ELLINGSEN et al., 2002; FREITAS et al., 2005, 2006; TĘGOWSKI, 2005; WIENBERG; BARTHOLOMA, 2005).

Acoustic seabed classification is based on parameters that quantify the substrate's acoustic responses, with high confidence and accuracy levels (TEGOWSKI, 2005). The Bottom Surface Backscattering Strength (BSBS) is proportional to the acoustic hardness or impedance of the seafloor. The proportion of reflected energy is determined by the coefficient of reflection as a function of the acoustic impedance of the medium (water) and of the reflector (MACLENNAN; SIMMONDS, 1992; SIMMONDS; MACLENNAN, 2005). BSBS data are expressed in decibels $(\mathrm{dB})$ as the $\log$ ratio between the incident energy and the energy reflected by the sea floor.

In this context, the present study produced a map of the acoustically conspicuous features of the seabed of the outer shelf and higher slope of the Pelotas basin between $28^{\circ} \mathrm{S}$ and $35^{\circ} \mathrm{S}$, based on BSBS data.

\section{Study Area}

12 The present study covered the Brazilian sector of the Pelotas basin, between parallels $28^{\circ} \mathrm{S}$ and $35^{\circ} \mathrm{S}$. The Uruguayan part of the basin is known as Cuenca del Este and extends as far as the La Coronilla basement. The Pelotas basin lies in a general NE-SW direction and covers an underwater area, extending as far as the $2,000 \mathrm{~m}$ isobath, of $170,000 \mathrm{~km}^{2}$.

The continental shelf is narrower in the northern sector, being about $110 \mathrm{~km}$ wide near Santa Marta Cape. In the south shelf-width attains $170 \mathrm{~km}$ at Rio Grande port. Mean depth at the South Brazilian continental shelf break is around $120 \mathrm{~m}$ (CORRÊA et al., 1996; COOKE et al., 2007).

As regards sediment distribution, the outer shelf consists predominantly of mud substrates, with the presence of sandy and sandy-biodetritic features with coral skeletons and mosaics where consolidated substrates may be found. The continental slope presents fine terrigenous segments derived from shelf relict deposits and a sandy fraction mainly consisting of planktonic foraminifera (ROCHA et al., 1975).

Along the outer shelf and the upper continental slope, tropical and subtropical waters transported by the Brazilian Current are the main surface water masses. The southern-most portion of the South Brazilian Continental Shelf is under the influence of the convergence of the Brazilian Current and the Malvinas Current. The confluence is usually located at latitude $36^{\circ} \mathrm{S}$ off the Argentinian Continental shelf, but undergoes seasonal variations as regards the position of the confluence (GORDON, 1981; PIOLA et al, 2000).

Along the inner shelf, the water masses are strongly influenced by the discharge of the Patos Lagoon and La Plata River, as well as by the intrusion of waters from the Uruguayan and Argentinian continental shelves (SOARES; MÖLLER, 2001; MÖLLER et al., 2008).

\section{Material and Methods}

\section{The Acoustic Method}

Acoustic energy at a frequency of $38 \mathrm{kHz}$ was transmitted regularly at a high ping rate from a split beam hull mounted transducer, connected to a Scientific EK 500 Echosounder. Energy decrease during transmission and reception, due to attenuation and geometric spreading, were compensated for by the Time Varied Gain (TGV) equation, as $20 \log \mathrm{R}+2 \alpha$ $R$, where $R$ is the range and $\alpha$ is the frequency dependent attenuation coefficient. The energy reflected back towards the sound source is the socalled backscattered energy. The EK 500 echo sounder makes these data available for the water column and the seafloor surface, in this case as the parameter Bottom Surface Backscattering Strength or BSBS. Therefore BSBS is a logarithmic relationship between the acoustic energy that reaches the bottom and the energy backscattered by the seabed surface. If the bottom is rough, meaning that it is uneven on the scale of the wavelength, some energy is scattered in 
directions other than that of the specular reflection (SIMMONDS; MACLENNAN, 2005).

\section{Collection of Acoustic Data}

The data used to generate seafloor acoustic backscattering maps were collected during six surveys. Three acoustic assessment surveys evaluated the pelagic resources under the project "Assessment of the Sustainable Potential of Live Resources of the Exclusive Economic Zone" (REVIZEE acoustic surveys) and three surveys were made under the project "Assessment of the Distribution and Abundance of Cetacea on the Southeast-South Brazilian Outer Continental Shelf and Slope: an Ecosystem Approach".

Acoustic data were acquired using the same scientific digital echo-sounder (SIMRAD), with an echo-integrator (model EK-500), calibrated according to Foote (1982) and Maclennan and Simmonds (1992). The system was coupled to a split-beam hull transducer on board the Research Vessel Atlântico Sul and the frequencies used were $38 \mathrm{kHz}$ and $120 \mathrm{kHz}$. Table 1 summarizes the information on the surveys and Figure 1 shows the survey designs of the six cruises.

\section{Data Processing and the Elaboration of sea Bottom Reflectivity Maps}

All the survey areas extended beyond the boundaries of the present study, which included only the Brazilian Pelotas Basin. Data for latitudes lower than $28^{\circ} \mathrm{S}$, which limit that basin, were excluded.

The acoustic data obtained at $38 \mathrm{kHz}$ were filtered in order to extract the parameters relevant for the present study from the output telegram. Using a filter software developed in Fortran language, the following information was extracted: V1 (hour, date, miles), GL (hour, latitude, longitude), and D1 (hour, depth, bottom hardness) and organized on ASCII spreadsheets.

These data were subsequently filtered using the advanced filter tool of Microsoft Excel. Aiming at standardizing acoustic reflectivity values and removing the errors that occurred during data acquisition, BSBS values higher than -5 and lower than $-30 \mathrm{~dB}$ were excluded from the spreadsheets.

The following step was to enter the data sheets containing a total number of $1,507,823$ BSBS values into a SIG (ArcMap( 9,3) system. The BSBS values were divided into four classes and displayed on ArcMap@ 9.3 using a color scale. BSBS value classes were defined according to Figueiredo $\mathrm{Jr}$ and Madureira (2004), who established four dB classes associated with sediments types (Table 2). According to those authors, the four classes of seafloor acoustic reflection values, expressed in $\mathrm{dB}$, were correlated with 10 sediment classes defined according to Shepard's triangular diagram, (SHEPARD, 1954) (Fig. 2). In order to achieve the characteristics of the sediments that cover the Brazilian continental margin, Figueiredo Jr and Madureira (2004) adapted Shepard's original triangular diagram and constructed a new one, taking muds (silt + clay), sands and gravels as major constituents (Fig. 2).

Table 1 . Summary of information on the surveys of the present study.

\begin{tabular}{|c|c|c|c|c|c|c|}
\hline $\begin{array}{l}\text { Acoustic } \\
\text { survey }\end{array}$ & REVIZEE I & REVIZEE II & REVIZEE III & $\begin{array}{c}\text { Slope Whales } \\
\text { I }\end{array}$ & $\begin{array}{c}\text { Slope Whales } \\
\text { II }\end{array}$ & $\begin{array}{c}\text { Slope Whales } \\
\text { III }\end{array}$ \\
\hline Ship & $\begin{array}{c}\text { N. Oc. } \\
\text { Atlântico Sul }\end{array}$ & $\begin{array}{c}\text { N. Oc. } \\
\text { Atlântico Sul }\end{array}$ & $\begin{array}{c}\text { N. Oc. } \\
\text { Atlântico Sul }\end{array}$ & $\begin{array}{c}\text { N. Oc. } \\
\text { Atlântico Sul }\end{array}$ & $\begin{array}{c}\text { N. Oc. } \\
\text { Atlântico Sul }\end{array}$ & $\begin{array}{c}\text { N. Oc. } \\
\text { Atlântico Sul }\end{array}$ \\
\hline Year & 1996 & 1997 & 1997 & 2009 & 2010 & 2010 \\
\hline Period & $\begin{array}{c}\text { Jul 15- Sep } \\
03\end{array}$ & $\begin{array}{c}\text { Apr 21-May } \\
26\end{array}$ & $\begin{array}{c}\text { Nov 06- Dec } \\
23\end{array}$ & $\begin{array}{c}\text { Oct } 21-\text { Jun } \\
11\end{array}$ & $\begin{array}{c}\text { Apr 22-May } \\
14\end{array}$ & $\begin{array}{c}\text { Oct } 19-\mathrm{Nov} \\
19\end{array}$ \\
\hline $\begin{array}{l}\text { Duration } \\
\text { (days) }\end{array}$ & 53 & 32 & 38 & 17 & 23 & 30 \\
\hline $\begin{array}{l}\text { Region } \\
\text { studied }\end{array}$ & $\begin{array}{c}\mathrm{RS} / \mathrm{SC} / \mathrm{PR} / \mathrm{SP} \\
\text { /RJ* }^{*}\end{array}$ & $\begin{array}{c}\mathrm{RS} / \mathrm{SC} / \mathrm{PR} / \mathrm{SP} \\
/ \mathrm{RJ}\end{array}$ & $\begin{array}{c}\mathrm{RS} / \mathrm{SC} / \mathrm{PR} / \mathrm{SP} \\
/ \mathrm{RJ}\end{array}$ & $\begin{array}{c}\mathrm{RS} / \mathrm{SC} / \mathrm{PR} / \mathrm{SP} \\
/ \mathrm{RJ}\end{array}$ & $\begin{array}{c}\mathrm{RS} / \mathrm{SC} / \mathrm{PR} / \mathrm{SP} \\
/ \mathrm{RJ}\end{array}$ & $\begin{array}{c}\mathrm{RS} / \mathrm{SC} / \mathrm{PR} / \mathrm{SP} \\
/ \mathrm{RJ}\end{array}$ \\
\hline $\begin{array}{l}\text { Depth } \\
\text { limits (m) }\end{array}$ & $100-2000$ & $100-2000$ & $100-2000$ & $100-2000$ & $100-2000$ & $100-2000$ \\
\hline $\begin{array}{l}\text { Track } \\
\text { extension } \\
(\mathrm{nm})\end{array}$ & 3161 & 3224 & 3310 & 1408 & 1595 & 2463 \\
\hline Probes & EK 500 & EK 500 & EK 500 & EK 500 & EK 500 & EK 500 \\
\hline $\begin{array}{l}\text { Tranducer } \\
\text { types and } \\
\text { frequencies }\end{array}$ & $\begin{array}{l}\text { Split- beam } \\
(38 \mathrm{kHz})\end{array}$ & $\begin{array}{l}\text { Split- beam } \\
(38 \mathrm{kHz})\end{array}$ & $\begin{array}{l}\text { Split- beam } \\
(38 \mathrm{kHz})\end{array}$ & $\begin{array}{l}\text { Split- beam } \\
(38 \text { e } 120 \\
\mathrm{kHz})\end{array}$ & $\begin{array}{l}\text { Split- beam } \\
(38 \text { e } 120 \\
\mathrm{kHz})\end{array}$ & $\begin{array}{c}\text { Split- beam } \\
(38 \text { e } 120 \\
\mathrm{kHz})\end{array}$ \\
\hline $\begin{array}{l}\text { Integration } \\
\text { interval }\end{array}$ & $1 \mathrm{~nm}$ & $1 \mathrm{~nm}$ & $1 \mathrm{~nm}$ & $1 \mathrm{~nm}$ & $1 \mathrm{~nm}$ & $1 \mathrm{~nm}$ \\
\hline
\end{tabular}




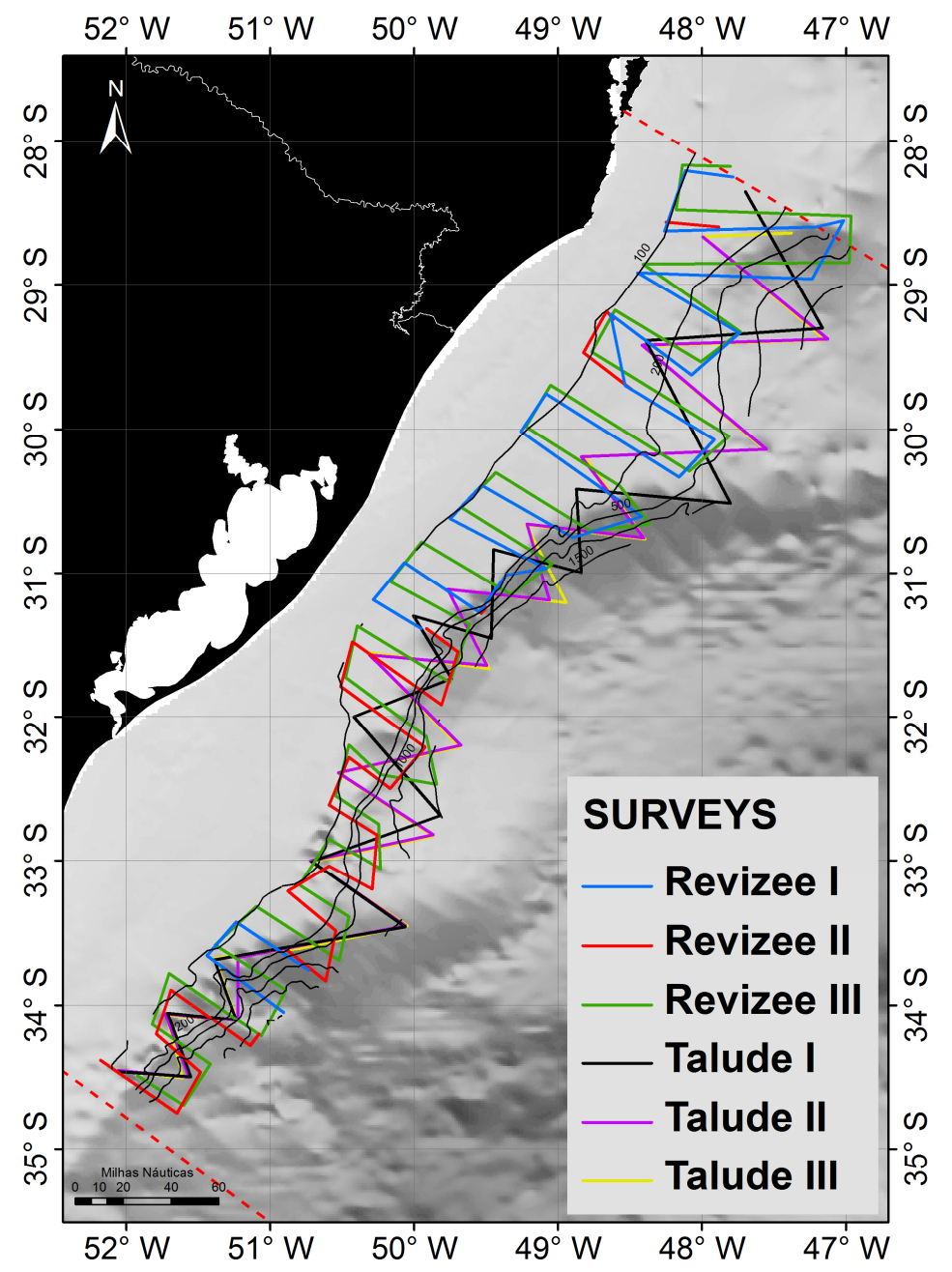

Fig. 1. Survey design of the REVIZEE 1, 2, 3 and Slope acoustic surveys in the area of the Pelotas Basin.

Table 2. BSBS classes as defined by FIGUEIREDO JR \& MADUREIRA (2004) and respective colors on the seafloor acoustic maps.

\begin{tabular}{|c|c|c|}
\hline BSBS class & Classification according to a modified Shepard's Triangular Diagram (see Figure 2) & $\begin{array}{l}\text { Corresponding } \\
\text { colors on the } \\
\text { acoustic map }\end{array}$ \\
\hline-5 to $-10 \mathrm{~dB}$ & $\begin{array}{l}\text { Gravel (10), silty gravel (9), sandy gravel (8), sand silt gravel (6), gravelly sand } \\
\text { (5),sand (1) }\end{array}$ & Red \\
\hline-10 to $-15 \mathrm{~dB}$ & Gravelly silt (7), sandy silt(3), silty sand (2), sand (1) & Yellow \\
\hline-15 to $-20 \mathrm{~dB}$ & Sandy silt (3), silt(4) & Green \\
\hline$<-20 \mathrm{~dB}$ & Silt (1) & Blue \\
\hline
\end{tabular}




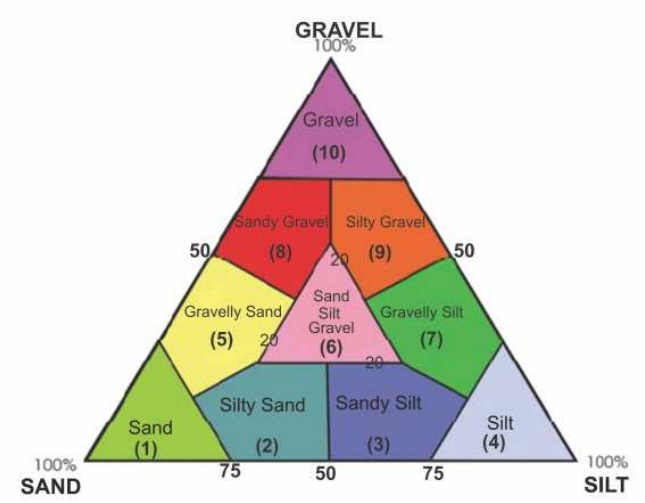

Fig. 2. Shepard's triangular diagram, modified from Shepard (1954).

Acoustic reflectivity data were interpolated by the Natural Neighbor method using the ArcMap@ 9.3 software program. This method uses Thiessen Polygons to determine the weights of the points and interpolates average neighboring points weighted according to the proportional areas (MAZZINI; SCHETTINI, 2009)
The acoustic maps generated in the present study were compared to others containing information on the sea bottom of the Pelotas Basin available in the literature.

\section{Results AND Discussion}

Figure 3 shows the 1,507,823 acoustic reflectivity values obtained on all the survey tracks plotted in the four $\mathrm{dB}$ classes defined by Figueiredo $\mathrm{Jr}$ and Madureira (2004). It is to be observed that, in the different surveys, neighboring survey tracks present similar and continuous reflectivity standards, as shown of Figure 3.

The BSBS distribution classes (Fig. 4) demonstrate that a series of high bottom reflectivity provinces are located at 100-200 $\mathrm{m}$ depth. The largest feature with this characteristic is present on parallel $29^{\circ} \mathrm{S}$, close to the region of Santa Marta Cape. Further south, on parallel $30^{\circ} \mathrm{S}$, this feature is partially continuous down to $500 \mathrm{~m}$ deep. Three other features, with high bottom reflectivity at 100-200 $\mathrm{m}$ depth, are located close to parallels $31^{\circ} \mathrm{S}, 33^{\circ} \mathrm{S}$ and $34^{\circ} \mathrm{S}$.

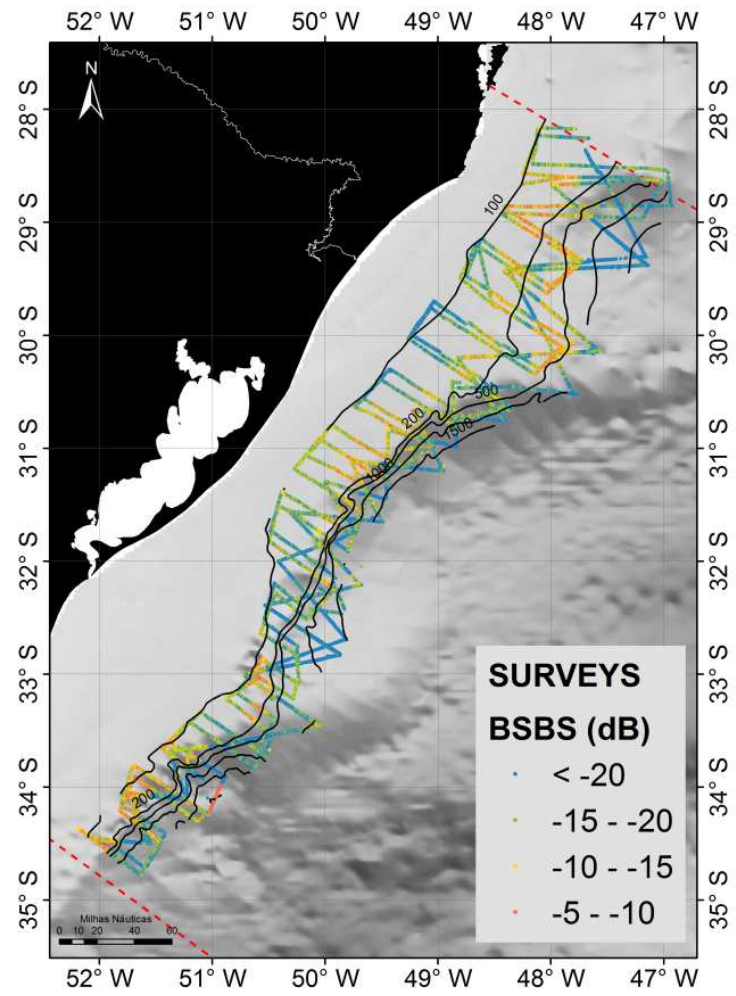

Fig. 3. Bottom surface backscattering strength (BSBS) values classified according to profile in the Pelotas Basin (REVIZEE 1, 2, 3 and Slope acoustic surveys). Areas with high acoustic reflectivity values are red. 


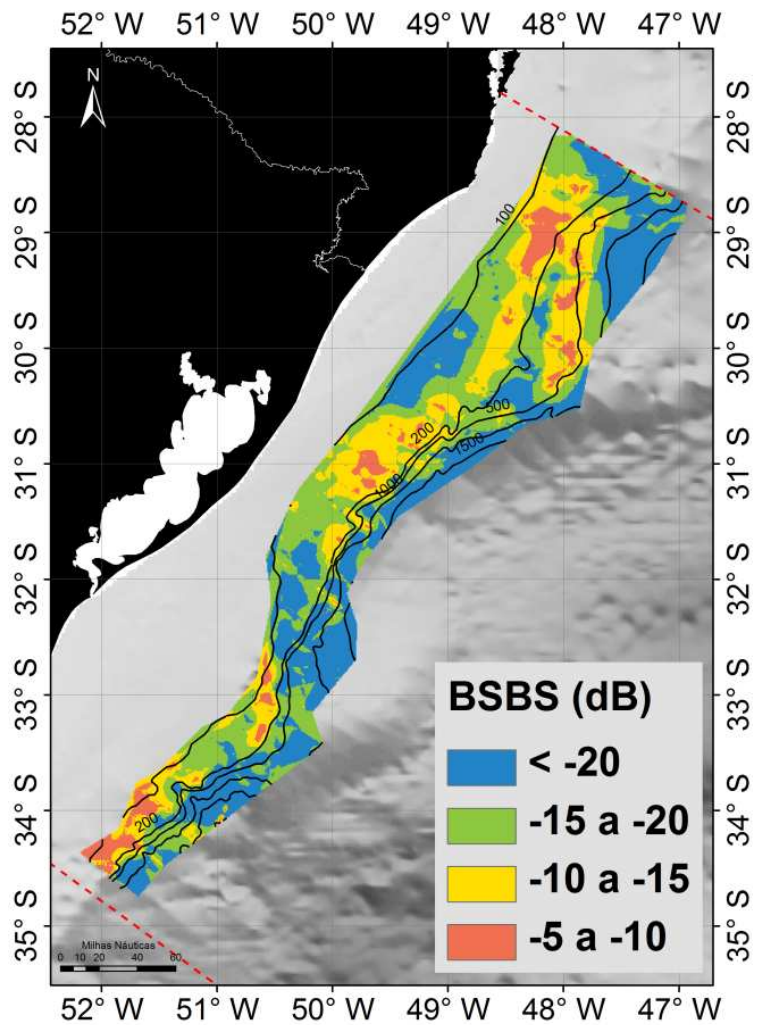

Fig. 4. Seabed Acoustic Map generated by the Natural Neighbor interpolation of BSBS values.

In general, bottoms with intermediate reflectivity values of -10 and $-20 \mathrm{~dB}$ predominate at 100-200 m depth and are represented on the map in yellow and green. Deeper than $500 \mathrm{~m}$, features with low acoustic reflectivity values are predominant $(<-20$ $\mathrm{dB})$.

Figueiredo Jr and Madureira (2004) correlated acoustic reflectivity values with sediment classes defined according to a modified Shepard's diagram as shown in Table 2, allowing the comparison of acoustic maps with sediment maps generated from data obtained from bottom samples.

The high reflectivity features observed between 100 and $200 \mathrm{~m}$ on the acoustic map are consistent with the areas indicating the presence of gravel and carbonate mapped in the Sediment Atlas of the Continental Shelf of Rio Grande do Sul (MARTINS; URIEN, 1977, 1979). According to the atlas there are areas between 100 and 200 m deep with up to $40 \%$ gravel and biodetritic limestone concentrations, and areas with up to $70 \%$ of carbonate. This high carbonate concentration is due to shell debris in this area.
The north of the studied area, around $29^{\circ} \mathrm{S}$ and $48^{\circ} \mathrm{W}$, presented high acoustic reflectivity values, where the Sediment Atlas of the Continental Shelf of Rio Grande do Sul (MARTINS; URIEN, 1977, 1979) indicates the presence of $25-50 \%$ of carbonate and 10$20 \%$ of gravel. Similarly, in the south $\left(30^{\circ} \mathrm{S} ; 50^{\circ} \mathrm{W}\right)$, the acoustic map indicates the presence of a high reflectivity feature, where the Atlas (MARTINS; URIEN, 1977, 1979) shows the presence of 50-75\% of carbonate and $30-40 \%$ of gravel.

These findings are consistent with the previous report of Figueiredo Jr and Madureira (2004), who attributed high acoustic reflectivity values to the presence of gravel and carbonate, as these sediment components are highly reflective. In general, the acoustic map identified the main features with gravel and carbonate concentrations between depths of 100 and $200 \mathrm{~m}$, as previously observed by Martins and Urien $(1977,1979)$.

The highly reflective feature found up to 200 $\mathrm{m}$ deep, on the Rio Grande Terrace, near $30^{\circ} \mathrm{S}$ and $48^{\circ} \mathrm{W}$, indicates the presence of $25-50 \%$ of carbonate and up to $10 \%$ of gravel in the sediment where sand and silty sand are predominant in the atlas of Martins 
and Urien,1977, 1979. In this region, previous reports indicate the presence of phosphate pockets. Klein et al. (1992) recorded the presence of these phosphate pockets in the Rio Grande Terrace, at a depth of 100$500 \mathrm{~m}$. Also in the same region, at around $500 \mathrm{~m}$ depth, Silva and Mello (2005) indicated the presence of phosphorite pockets with 15-16 \% P2O5 content. Cooke et al. (2007) suggested the presence of phosphate deposits in the region based on the features observed in echograms and high acoustic reflectivity values. Therefore, the high acoustic reflectivity of the Rio Grande Terrace observed on the acoustic map elaborated in the present study may be attributed to phosphate pockets, which are highly reflective surfaces.

When the acoustic map generated in the present study is compared with those published by Figueiredo $\mathrm{Jr}$ and Madureira (2004), it is to be observed that the distribution of BSBS classes in the area is similar in both (Fig. 5). However, in the present study, a high reflectivity feature was found in the south, close to parallel $34^{\circ} \mathrm{S}$, which was not evidenced by Figueiredo Jr and Madureira (2004), who reported only traces of high reflectivity in this region. The presence of this high reflectivity feature may be attributed to highly reflective components in the sediments, which is confirmed by the Sediment Atlas of the Continental Shelf of Rio Grande do Sul (MARTINS; URIEN, 1977, 1979) that shows, in the same region $\left(34^{\circ} \mathrm{S}\right.$, between longitudes $51^{\circ} \mathrm{S}$ and $52^{\circ} \mathrm{S}$ ), 10 to $20 \%$ gravel and 25 to $50 \%$ carbonate in the sediment. In this study, the processing of a larger database allowed these areas to be mapped at a higher resolution.

Figueiredo Jr and Madureira (2004) generated sedimentological maps and sediment composition maps based on 3,036 superficial samples collected in the southeastern and southern regions (Figs 6B and 7B, respectively). The sedimentological map was created using statistical grain size parameters (mean, median, standard deviation). This map shows the predominance of mud sediments in those regions, with the presence of gravelly sand on parallels $29^{\circ} \mathrm{S}$ and $31^{\circ} \mathrm{S}$ (Fig. 5C). The high reflectivity features identified in the present study coincide with those areas, which are however, defined as more extensive and continuous provinces. The sediment composition map was generated by a qualitative mapping of mineral substances and organic compounds. The Figueiredo Jr and Madureira (2004) map indicates the presence of bioclastic materials at Santa Marta Cape, which is consistent with the high reflectivity area found on the map generated in the present study (Fig. $6 \mathrm{~A})$.

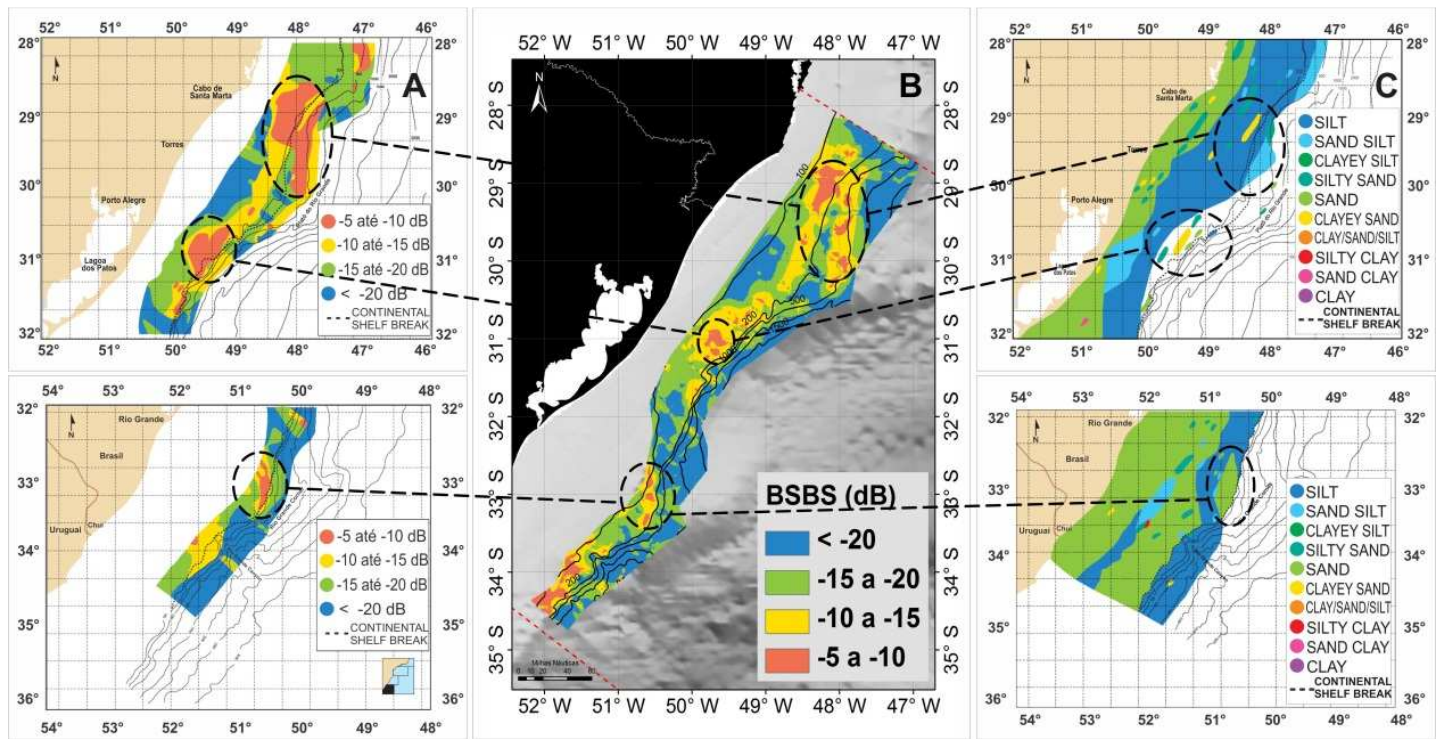

Fig. 5. Seabed Acoustic Map generated by FIGUEIREDO JR \& MADUREIRA (2004) (A); Seabed Acoustic Map generated in the present study (B); Sedimentological map generated by FIGUEIREDO JR \& MADUREIRA (2004) (C). Areas with high acoustic reflectivity values are highlighted. 


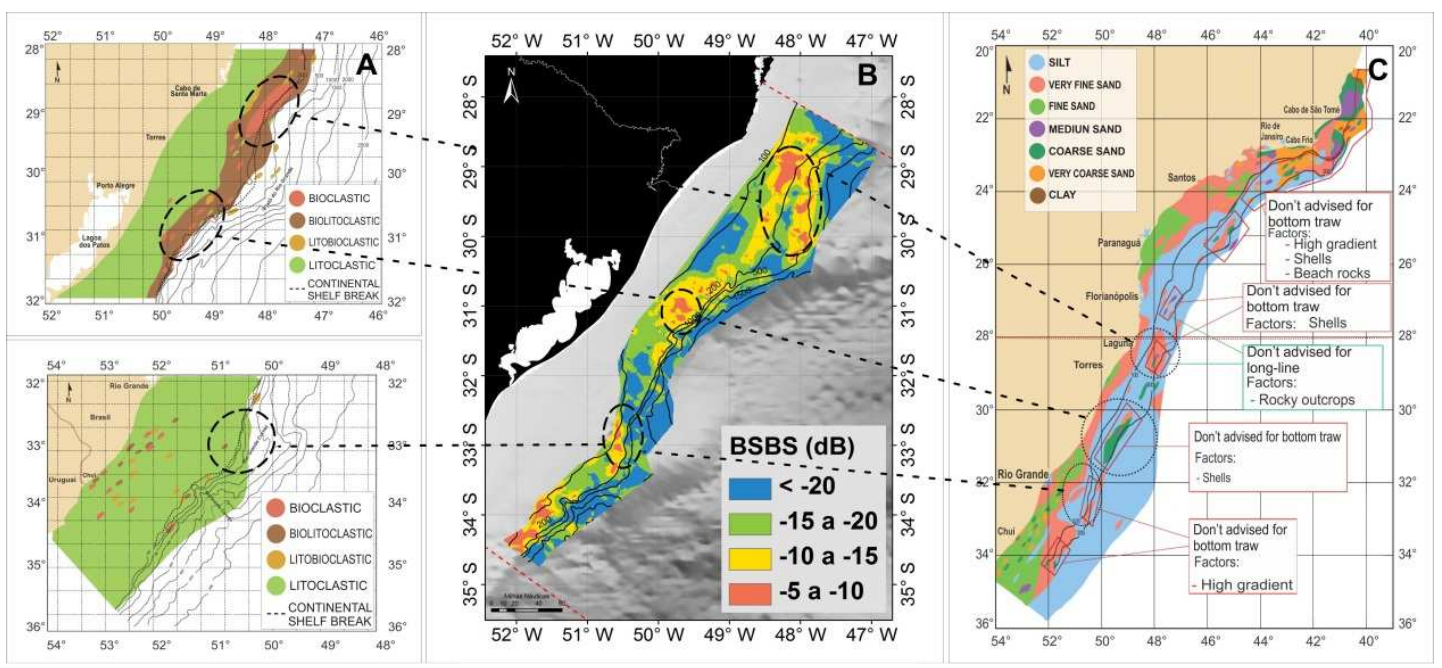

Fig. 6. Sediment composition map generated by FIGUEIREDO JR \& MADUREIRA (2004) (A); Seabed Acoustic Map generated in the present study (B); Sedimentological map generated by FIGUEIREDO JR \& TESSLER (2004) (C). Areas with high acoustic reflectivity values are highlighted.

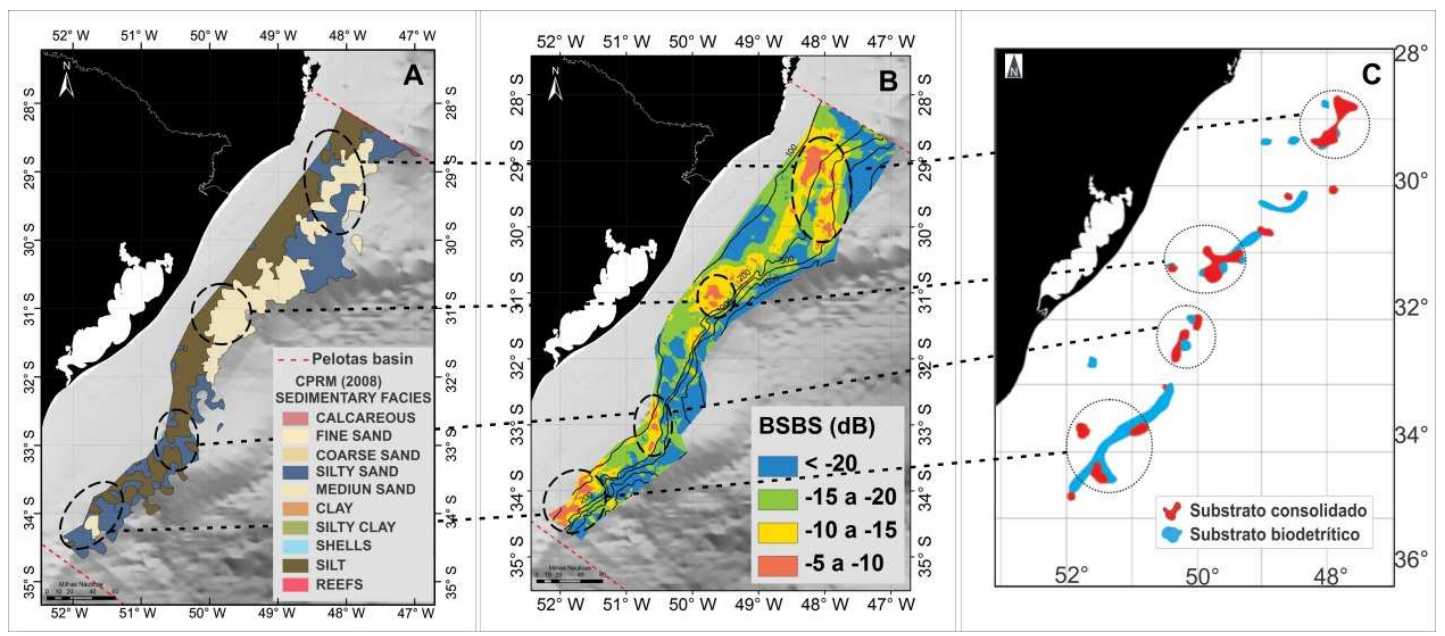

Fig. 7. Sedimentological feature map (CPRM, 2008) (A); Seabed Acoustic Map generated in the present study (B); Outcrop areas of consolidated and biodetritic substrates proposed by KITAHARA et al. (2008) based on coral species (C). Areas with high acoustic reflectivity values are highlighted.

CPRM (2008) (Companhia de Pesquisa de Recursos Minerais - Mineral Resources Prospecting Company) published a sea bottom sedimentological map using data from the geological database of the Brazilian Legal Continental Shelf and Adjacent Oceanic Areas and also data from the National Oceanographic Database, which added information from 2,386 records of sediment samples classified as belonging to ten different features (Fig. 7A). Only three seabed descriptions (medium sand, silty sand, and silty) were defined on that map for the
Pelotas Basin region. In general, the absence of specific information on sediment characteristics, or the long distance between samples, may have resulted in misleading inferences or excessive stringency that may greatly limit knowledge of the superficial distribution of sediments (FIGUEIREDO JR; MADUREIRA, 2004). Although the sampling network of the map generated by CPMR indicates a good coverage, the presence of biodetritic sediments is not mentioned, as observed in previous studies on the Pelotas Basin (MARTINS; URIEN, 1977, 1979; 
FIGUEIREDO JR; MADUREIRA, 2004; FIGUEIREDO JR; TESSLER, 2004) and also on the acoustic map elaborated in the present study which show high reflectivity areas that may be attributed to the presence of a consolidated and/or biodetritic bottom.

Kitahara et al. (2008) generated a map interpolated for biodetritic and consolidated bottom type using information on the environmental restrictions related to this substrate, where coral species live. Comparing the maps of Kitahara et al. (2008) with those of the present study it is clear that the features follow similar trends, particularly the three high reflectivity features found between the 100 and $200 \mathrm{~m}$ isobaths (Figs 7B and 7C). The maps of Kitahara et al. (2008) of these areas indicate the presence of consolidated sea bottoms, followed by a bottom continuum with biodetritic material (Figure 7C). In this case, when the interpolated, acoustic and deep coral maps are compared, the results are more coherent, suggesting that high BSBS values indeed indicate the presence of coral related to consolidated and/or biodetritic sea bottoms.

\section{Conclusions}

The present study employed data obtained in six surveys carried out in the Pelotas Basin, including three additional surveys beyond those given by the study of Figueiredo Jr and Madureira (2004). A larger data base processed by the Natural Neighbor interpolation method allowed the generation of more detailed and higher resolution acoustic backscattering maps.

The higher resolution allowed the identification of a high reflectivity area in the south, between 100 and $200 \mathrm{~m}$, close to the parallel $34^{\circ} \mathrm{S}$. In Figueiredo Jr and Madureira (2004) this feature had been identified but as limited to a smaller area.

Several acoustic parameters to map seafloors are used worldwide and present some advantages over the traditional methods that make specific collections of sediments. The assessment of sea bottom variability by these latter traditional methods is made by sediment sampling using bottom grabs, corers or diving, which present high complexity and high operational costs, particularly in deep waters. Therefore, detailed maps of deep water sediment mosaics are lacking in many sectors of all the oceans. On the other hand, acoustic sampling allows the scanning of large areas in a short time, making it an essential tool for the mapping of deep waters in areas where sediment mapping campaigns are not frequent.

Most of the currently available geological maps of Brazil do not cover areas deeper than $500 \mathrm{~m}$. The map prepared during the present study interpolated 1,365,559 acoustic reflectivity values obtained from sequential reflectivity readings of the sea bottom of the Pelotas Basin, resulting in a broad coverage of the area not included in sedimentological maps of the region. However, acoustic maps should be interpreted with caution as validation is essential in order to correlate acoustic responses with sedimentological information. Therefore, it is emphasized that adequate acoustic maps also depends on the knowledge of the sediments of a region for comparison and validation. Thus we present the results of the present study as being compatible with the sedimentological information previously available for the Pelotas Basin.

The extreme south of the Brazilian coast is considered a very important fishing area (HAIMOVICI et al., 1989; CASTELLO et al 1997) where oceanographic conditions favor the development of pelagic and demersal fish stocks. The lack of georeferenced data on the sea bottom types and characteristics over a wide fishery area has limited the understanding of living resources distribution patterns and their association with the different habitats of that region. The acoustic map generated in the present study may contribute to the making of well-founded decisions on proposals for adequate fishery management in that region.

\section{ACKNOWLEDGEMENTS}

The authors wish to thank Eduardo Secchi for kindly providing the data for the Slope Whales Surveys. We would also thank the team of the "Laboratory of Fisheries Technology and Hydroacoustics" of the Oceanography Institute of Federal University of Rio Grande.

\section{REFERENCES}

ANDERSON, J. T.; GREGORY, R. S.; COLLINS, W, T. Acoustic classification of marine habitats in coastal Newfoundland. ICES J. Mar. Sci., v. 59, n. 1, p. 156$167,2002$.

ANDERSON, J. T.; HOLLIDAY, D. V.; KLOSER, R.; REID, D. G.; SIMARD, Y. Acoustic seabed classification: current practice and future directions. ICES J. Mar. Sci., v. 65. 2008.

CASTELLO, J. P, M. HAIMOVICI, C. ODEBRECHT \& C. M. VOOREN. Relationships and Function of Coastal and Marine environments: the continental shelf and slope. In: Subtropical Convergence Environments: the Coastal and Sea in the Southwestern Atlantic, (171-178). Seeliger, U.; Oderbrecht, C. \& Castello, J.P. (eds) Springer, 1997.

COLLINS, W.; GREGORY, R. S.; ANDERSON, J. T. A Digital Approach to Seabed Classification. Sea Technol., v. 37, n. 8, 1996.

COOKE, C. V.; MADUREIRA, L. S. P.; GRIEP, G. H.; PINHO, M. P. Análise de dados de ecossondagem de fundo oriundos de cruzeiros realizados entre Fortaleza (CE) e Chuí (RS) com enfoque na morfologia e tipos de fundo. Rev. Bras. Geofis., v. 25, 4, p. 443-457, 2007. 
CORRÊA, I. C. S; MARTINS, L. R. S.; KETZER, J. M. M ELIAS, A. R. D.; MARTINS, R. Evolução sedimentológica e paleogeográfica da plataforma continental sul e sudeste do Brasil. Notas Téc., CECO/UFRGS, v. 9, p. 51-61, 1996.

CPRM - Cia. de Pesquisa de Recursos Minerais. Geologia e Recursos Minerais do Estado de São Paulo: Sistemas de Informações Geográficas (SIG). Programa Geologia do Brasil: Integração, atualização e difusão de dados da Geologia do Brasil. Mapas Geológicos Estaduais escala 1:750000. Brasília, DF: MME, 2008. (CD-ROM).

ELLINGSEN, K .E.; GRAY, J. S.; BJORNBOM, E. Acoustic classification of seabed habitats using QTC VIEW system. ICES J. Mar. Sci., v. 59, n. 5, p: 825-835, 2002.

FIGUEIREDO JR, A. G.; TESSLER, M. G. Topografia e composição do substrato marinho da região SudesteSul do Brasil. São Paulo: Instituto Oceanográfico-USP, 2004. 64 p. (Série Documentos REVIZEE/SCORE SUL, V.1).

FIGUEIREDO JR, A. G.; MADUREIRA, L. S. P. Topografia, composição, refletividade do substrato marinho e identificação de províncias sedimentares na Região Sudeste-Sul do Brasil. São Paulo: Instituto Oceanográfico-USP, 2004. 64 p. (Série Documentos REVIZEE/SCORE SUL, v. 1).

FOOTE, K. J. Optimizing copper spheres for precision calibration of hydroacoustic equipament. J. Acoust. Soc. Am., v. 71, p. 742-747, 1982.

FREITAS, R.; SAMPAIO, L.; RODRIGUES, A. M.; QUINTINO, V. Sea-bottom classification across a shallow-water bar channel and near-shore shelf, using single-beam acoustics. Estuar. Coast. Shelf Sci., v. 65, n. 4, p. 625-632, 2005.

FREITAS, R.; SAMPAIO, L.; OLIVEIRA, J.; RODRIGUES, A.M.; QUINTINO, V. Validation of soft bottom benthic habitats identified by single-beam acoustics. Mar. Pollut. Bull., 53(1-4): 72-79, 2006.

GORDON, A. South Atlantic thermohaline ventilation. Deep Sea Res., v. 28A, n. 11, p. 1238-1264, 1981.

HAIMOVICI, M, PEREIRA, S. D. AND VIEIRA, P. C. La pesca demersal en el sur do Brasil en el periodo 19751985. Frente Maritimo, 5(A): 151-163, 1989.

HOGARTH, W. T. Keeping our fisheries sustainable. In: BARNES P. W.; TOMAS, J. P. (Ed.). Benthic habitats and the effects fishing. Bethesda, Maryland: American Fisheries Society, 2005. (Symposium on effects of fishing activities on benthic habitats, 41, 2005. Proceedings p. 11-17).

KITAHARA, M. V.; HORN FILHO, N. OLMIRO; ABREU, J. G. N. Utilização de registros de corais de profundidade (Cnidaria, Scleractinia) para prever a localização e mapear tipos de substratos na plataforma e talude continental do sul do Brasil. Pap. Avulsos Zool., São Paulo, vol. 48, n.2, 2008,

KLEIN, A. H. F.; GRIEP, G. H.; CALLIARI, J. L.; VILLWOCK, J. A. Ocorrências de concreções fosfáticas no terraço de Rio Grande. In: CONGRESSO BRASILEIRO DE GEOLOGIA, 37. Camboriú, SC. Resumos Expandidos p. 202-203, 1992.

MACLENNAN, D. N.; SIMMONDS, E. J. Fisheries Acoustics. London: Chapman \& Hall, 1992. 325 p. (Series 5).
MARTINS, L. R.; URIEN, C. M. Atlas sedimentológico da Plataforma Continental do Rio Grande do Sul. Porto Alegre: CECO/UFRGS, 1977. (Série Mapas).

MARTINS, L. R.; URIEN, C. M. Atlas Sedimentológico da Plataforma Continental do Rio Grande do Sul.Porto Alegre: CECO/UFRGS, 1979. (Série Mapas).

MAZZINI, P. L. F.; SCHETTINI, C. A. F. Avaliação de metodologias de interpolação espacial aplicadas a dados hidrográficos costeiros quase- sinóticos. Braz. J. Aquat. Sci. Technol., v. 13, n. 1, p. 53-64, 2009.

MÖLLER JR, O. O.; PIOLA, A. R.; FREITAS, A. C.; CAMPOS, E. The effects of river discharge and seasonal winds on the shelf off Southeastern South America. Continent. Shelf Res., v. 28, p. 1607-1624, 2008.

ORLOWSKI, A. Application of acoustic methods to correlation of fish density distribution and the type of sea bottom. Proc. IOA, Pt. III, v. 11, p. 179-185, 1989.

PIOLA, A. R.; CAMPOS, E. J. D.; MÖLlER JR., O. O.; CHARO, M.; MARTINEZ, C.M. Subtropical shelf front off eastern South America. J. Geophys. Res., v. 105 (C3), p. 6566-6578, 2000.

ROCHA, J. M.; MILLIMAN, J. D.; SANTANA, C. I.; VICALVI, M. A. Southern Brazil. Upper continental margin sedimentation off Brazil. Contr. Sedimentol., v. 4, p. 117-150, 1975.

SHEPARD, F. P. Nomenclature based on sand-silt-clay ratios. J. Sediment. Petrol., v. 24, v. 3, p. 151-158, 1954.

SILVA C. G.; MELLO. S. L. M. Nossas riquezas no mar: Recursos não-vivos. In: Ministério da Educação, Secretária da Educação Básica. O mar no espaço geográfico brasileiro. Coleção Explorando o Ensino. v. 8, Cap. 5, 160-178, 2005.

SIMMONDS, E. J.; MACLENNAN, D. N. Fisheries Acoustics: Theory and practice. 2nd ed. London: Blackwell Science, 2005. p. 437.

SOARES, I.; MÖLLER, O. Low-frequency currents and water mass spatial distribution on the Southern Brazilian Shelf. Cont. Shelf Res., v. 21, n. 16-17, p. 1785-1814, 2001

TEGOWSKI, J. Acoustical classification of bottom sediments in southern Baltic Sea. Quatern. Int., v. 130, p. $153-161,2005$

WIENBERG, C.; BARTHOLOMA, A. Acoustic seabed classification in a coastal environment (outer Weser Estuary, German Bight) - a new approach to monitor dredging and dredge spoil disposal. Cont. Shelf Res., v. 25 , p. $1143-1156,2005$

(Manuscript received 14 April 2011; revised 29 November 2012; accepted 17 January 2013) 